\title{
A Study on Chinese College English Teaching Reform with the View of Teachers
}

\author{
Chao $\mathrm{Yu}$ \\ Foreign Language School \\ Yanbian University \\ Yanji, China
}

\author{
Cong Qi \\ Normal School \\ Yanbian University \\ Yanji, China
}

\begin{abstract}
With an overall start of the curriculum reform in the field of basic education, the college English teaching reform in China started in 2004. However, although some great achievements on college English teaching reform have been made in many aspects during the last ten years, some problems still exist. For college English teachers, they need to update the teaching concept and strengthen the ability of teaching reflection; in addition, they also need to get rid of the sense of job burnout as soon as possible. The paper argues that we can take the following measures to make college English teachers be better: firstly, to establish college English teachers' development community; secondly, to make the pattern of "learning to each other" are institutionalized; thirdly, to improve college English teachers' professional development system.
\end{abstract}

Keywords-college English teaching reform; development predicament; college English teachers

\section{INTRODUCTION}

In 2004, the Ministry of Education officially enacted College English Curriculum Teaching Requirements to all colleges and universities in China, which marked the beginning of college English teaching reform in China. Up to now, scholars have got many theoretical and practical achievements which are relevant to the college English teaching reform. The research field involves college English teaching model, college English teaching method, college English teaching assessment and so on. Although we've got lots of achievements, we also have to admit at present the college English teaching reform in China has encountered unprecedented difficulties and so many people have some doubts about the quality of college English education. It is no doubt there are many subjective and objective reasons for the formation of this dilemma, but as the direct operator of college English teaching reform, college English teachers cannot get rid of the involvement. Therefore, basing on a reflection of the current situation of college English teaching reform in China, the paper revealed the factors hindering the college English teaching reform and put forward concrete measures to solve the problem, aiming to provide some beneficial reference to deepen the college English teaching reform.

\section{CURRENT SituATION OF COLLEGE ENGLISH TEACHING}

College English Curriculum Teaching Requirements promulgated in 2004 made a new top-level design to the college English teaching in China. It made clear rules or directional guidance of the nature and goal of college English teaching. But during the past ten years, although all kinds of teaching models, education concepts, teaching methods emerged, "various reforms give us the sense of rhetorical, most students who graduated from colleges cannot achieve the requirements of College English Curriculum Teaching Requirements, they also cannot effectively use English for communication"[1]. "Sophomore is not as good as freshman, junior is not as good as sophomore, and senior is not as good as junior is a popular saying for college students at present"[2]. The majority of students said the college English courses that they have taken have done little to improve their English. With students' own words, college English curriculum is so bad and the greatest sense of enrollment in this course is to obtain graduation requirements. Jigang Cai also showed that many of the college students are not satisfied with the English teaching. Facing all these problems existing in college English teaching reform, Bailing Liao pointed out " although there are many reasons for low quality of college English teaching, the biggest weakness is the teaching method, most of the students hope to change the current college English teaching model" [3]. So we can say that many mismatching problems and even the bottleneck of development on college English teaching in China have something wrong with college English teachers. In view of this, it is necessary to talk about how college English teachers have obstructed the development of college English teaching reform in China, and put forward some specific measures to improve college English teachers' comprehensive quality and effectively promote the development of college English teaching reform.

\section{PROBLEMS OF ENGLISH TEACHERS}

\section{A. Teaching Philosophy Is Backward}

Objectively speaking, the current situation of college English teachers' teaching concept and professional quality is not optimistic. According to Xiao Wang's research, "the current situation of Chinese English teachers is that many 
English teachers have insufficient English knowledge and the knowledge structure is not suitable for teaching requirements"[4].In 2014, Dongmei Chang pointed out that "in general, English teachers are lack of the scientific research capacity and their consciousness of teaching reform is weak"[5]. Yanbing Wang studied and pointed out that" there are still quite a few problems in the college English teaching, some teachers are accustomed to the "cramming teaching methods' and their teaching philosophy is backward, they are reluctant to learn to use modern language teaching equipment"[6]. Moreover, Yangjing Su (2017), Li Du (2013), Ling Cai (2012) and other scholars also believed that at present college English teachers' overall quality is not high. To sum up, it can be said that some college English teachers with low comprehensive quality of education teaching have become the most important factor hindering the further development of college English teaching reform in China.

\section{B. Lack of Teaching Reflective Consciousness and Ability}

Wallance thought that if foreign language teachers want to get a wonderful professional development, they have to continuously reflect their teaching practice and revise in practice. Posner, an American psychologist, proposed a teachers' growth formula in 1989, 'growth =experience+ reflection'. It means that reflection is a quality which good teachers should have and it is also the impetus to promote teachers' professional growth. However, according to the research results of Jinfen $\mathrm{Xu}$, "the overall reflection level of college English teachers in China is average"[7].This research conclusion has certain representativeness because the research objects are 1221 college English teachers who come from 16 different colleges and universities in China. And it is also pointed out that at present Chinese college English teachers are lack of the ability of teaching reflection and they ignored the reflections on their own teaching activities. What is most distressing is that many college English teachers have left "reflection" behind, they are not willing to find reasons from themselves, never reflect on their own teaching methods or teaching methods. To sum up, from the perspective of a relationship between teachers' teaching reflection ability and teaching reform, some college English teachers who are lack of reflection ability are the main obstacles to the further development of college English teaching reform in China.

\section{Job Burnout Is Widespread}

Maslach defined job burnout as a symptom of emotional exhaustion, dehumanization, and a low sense of achievement in a human-oriented career. The three core components are: emotional exhaustion, it means a complete loss of work enthusiasm; dehumanization or deindividuation, that means individuals treat the working object with a negative or insensitive manner; low sense of achievement, that means individuals have a lower tendency to evaluate their own meaning and value. "During the past decade, with a deepening reform of college English teaching in China, a large number of college English teachers appeared different degree of anxiety, and the higher level of anxiety leads to teachers' occupational burnout"[8]. Ping Liu took 300 English teachers in Nanjing Universities as the research objects, making a research on the problem of college English teachers' job burnout, the results showed that "college English teachers in China show a mild emotional exhaustion and moderate dehumanization, they are lack of the personal accomplishment seriously"[9].Li Liu also pointed out, "at present it is common that college English teachers have a job burnout in China, they are not willing to engage in the scientific research and teaching reform and often feel tired or are at a loss in the teaching process"[10].Frankly speaking, all kinds of job burnout phenomenon exist in Chinese colleges and universities. To sum up, college English teachers' job burnout directly affects the quality of college English teaching reform in China.

\section{COUNTERMEASURES FOR THE DEVELOPMENT OF COLLEGE ENGLISH TEACHING REFORM}

\section{A. Establish English Teachers' Development Community and Renew Teaching Concept}

A lot of practice has proved that a teacher development community can play an effective positive role in enhancing the teaching quality and promoting the professional development for teachers. So college English teachers' development community should be established in every colleges and universities. According to the actual needs of English teaching reform and development, the leader of the English teachers' development community can actively seek a certain material and policy support from the functional departments, aiming to effectively promote an update of teachers' education teaching idea and make all teachers get good professional development. It is no doubt that the update of teaching concept is inseparable from the policy and financial support of the school, but college English teachers should not wait for the arrangement of the school passively. At the same time, in order to communicate well with more people, teachers should actively attempt to set up different types of teachers' development community which are based on language skills or others. All teachers should strive to improve their own professional quality, optimize the structure of the existing knowledge and gradually accept various education teaching concepts and teaching methods from different perspectives.

\section{B. Make the Pattern of "Learning to Each Other" Be Institutionalized}

Although it has some subjective factors for Chinese college English teachers to be lack of the teaching reflection consciousness and the reflection ability, to some extent, the pattern of "closed teaching" in colleges and universities is one of the reasons. It not only provides an umbrella for teachers to teach at random but also cut off teachers' communication with others. And it makes teachers lose an opportunity to learn from others and to achieve selfprofessional development. The pattern of "closed teaching" not only prevents some excellent teachers from spreading their good educational teaching experience, but also prevents some teachers from being found their shortcomings timely. "Closed teaching" is not conducive to college English teachers' professional development and the college English 
teaching reform in China, it has become a stumbling block to hinder the healthy development of college English teaching reform. Therefore, if we can establish a system called "learning to each other" and make it institutionalization, normalization, then it can thoroughly break the barrier of the closed teaching. If we can make teachers accept the teaching management departments' supervision actively but not passively, then it not only can make teaching management perform the duties of supervision and guidance well, but also can promote teachers' teaching reflection constantly. And, of course, this paper argues that the implementation premise of the pattern of "learning to each other" is the instructor's permission, we have to know the instructor is the direct operator of classroom teaching and management. So this paper argues that in order to make the pattern of "learning to each other" be implemented well, the department of teaching management should do something followed: firstly, in order to get enough understanding and good support from instructors, we have to make teachers fully realize that the implementation of the work is a good way to improve the quality of English teaching, and it is also the important measure to help teachers achieve professional development better; secondly, this activity can be carried out among teachers with rich teaching experience, and gradually spread out from point to point, from individual to all; finally, the department of teaching management should formulate a corresponding incentive system to give spiritual and material rewards to the teachers who are willing to take part in the teaching reform, which can encourage more teachers to take part in the teaching reform.

\section{Improve English Teachers' Professional Development System and Solve the Problem of Job Burnout}

Although it has certain social and personal factors to the being of job burnout for college English teachers, the working environment in school has a very important influence on it. If teachers are able to improve their professional ability and comprehensive quality, to experience a strong personal accomplishment, then it can effectively eliminate their sense of job burnout. So the functional departments should be positive to provide powerful support and policy guarantee for the promotion of college English teachers' professional literacy. In fact, College English Curriculum Teaching Requirements also clearly states that schools should strengthen the training of English teachers so that they can adapt to the new English teaching model as soon as possible. At the same time, teachers should reasonably be arranged enough academic holidays and further study to ensure that their academic level and teaching methods are constantly improved. For this purpose, on the one hand, the functional departments should actively provide teachers some professional development platforms, strengthen the career planning and guidance to teachers, help teachers to overcome the sense of job burnout, enable them to establish a correct career concept and make them be willing to participate in college English teaching reform. On the other hand, the administrative department should take the responsibility to provide the conditions for college English teachers to communicate with other college's English teachers, and actively widen the channels for teachers to study at home and abroad. Finally, the functional departments also can arrange some ordering training according to teachers' actual needs, and actively invite relevant experts and excellent first-line teachers to make a report or communicate with each other.

\section{CONCLUSION}

As the direct operator of the college English teaching reform in China, college English teachers' problems are not allowed to ignore and avoided. With a critical perspective, the paper talked about how college English teachers prevented the college English teaching reform from a further development and put forward some concrete measures to solve the problem. It is hoped that this article can cause more and more people's attention on the problem of college English teaching reform, and more and more people can work together to seek how to make college English teachers be positive explorers and operators to the English teaching reform.

\section{REFERENCES}

[1] RuifangTu. Guiding college English teaching reform with demand theory [J]. Journal of Kaifeng education college, 2015, 35 (4): 90-91.

[2] Yan Dong. Research on the orientation of college English teaching reform in applied undergraduate universities [J].Jiangsu higher education, 2014, (4): 99-100.

[3] Bailing Liao. Discussion on the reform of college English curriculum [J]. Chinese higher education research, 2015, (1): 96-101.

[4] Xiao Wang. Professional development of college English teachers from an ecological perspective [J]. Journal of North China electric power university (social science edition), 2015 (1): 137-139.

[5] Dongmei Chang. Research on the current situation and improvement of the teaching staff of college English teachers [J]. Education and occupation, 2014 (6) : 91-92.

[6] Yanbing Wang. Existing problems and countermeasures in college English classroom teaching [J]. Education exploration, 2013 (5): 4041.

[7] Jinfen $\mathrm{Xu}$. Investigation and research on the current situation of teaching reflection of English teachers in Chinese universities [J]. Foreign language, 2012 (4): 6-15.

[8] Xin Wang. Analysis of the current situation and countermeasures of state anxiety during teacher transformation under the situation of college English teaching reform $[\mathrm{J}]$. Foreign language teaching theory and practice, 2015 (2): 31-38+95.

[9] Ping Liu. A study on the relationship between self-efficacy and job burnout among college English teachers [J]. Foreign language teaching, 2014, 35 (6): 68-72.

[10] Li Liu. Career burnout of college English teachers and career development path analysis in information technology environment $[\mathrm{J}]$ Journal of foreign language studies, 2014 (6): 136-139. 